\title{
The Impact of Tourists' Visit Number on the Regional Own Revenue
}

\author{
Imas Purnamasari, Gita Dwi Rahmi \\ Faculty of Economic and Business Education \\ Universitas Pendidikan Indonesia \\ imaspurnamasari@upi.edu
}

\begin{abstract}
The main aim of this research is to determine the impact of tourists' visit number on the regional own revenue in West Java Province. This research used descriptive and verivicative method. The data was collected by using documentation study technique. The research used the annual data that is published by Culture and Tourism Department of West Java Province which consists of the number of tourists' visit and regional own revenue from 26 cities and regencies in West Java during 2009-2014. The data was analyzed by using simple linear regression analysis, which is preceded by a test for linearity as a prerequisite regression test then testing the significance of regression ( $F$ test) and regression coefficient significance test ( $t$ test). The result showed that the number of tourists' visit has a positive impact on the regional own revenue. If the number of tourists' visit is increasing 1 person, the regional own revenue will increase $6.526,834$ times.
\end{abstract}

Keywords : Tourist visit, regional own revenue, decentralization

\section{INTRODUCTION}

Decentralization is usually referred as the transfer of powers from central government to lower levels in a politicaladministrative and territorial hierarchy. That powers are related to decions making so the result can be more effective and efficiency. The government has a regulation to ensure that decentralisation process in Law No 32 of 2004 [1], which tells us" that Government carries out the autonomy as much as they could, except government business that becomes government business, and the purpose is to increase public welfare, public services, and the regions competitiveness".

Decentralization causes a financial relation between government and regions. Deddi and Ayuningtya [2] mentioned, "A financial balancing between Government and regions including finance distribution between government and regions proportionally, democratically, conscionable, and transparently, which concerns regions needs and its potency". Autonomy can increase creativity of the citizen and also they role in their regions development. It gives a big chance to explore their own natural resource. Related to that, tourism industry becomes one of most potential income from tax and retribution, this is in accordance with the opinion Suwantoro, $G$ [3] "The tourism industry is often considered as an answer to the economic problems facing Indonesia".
West Java is one of provinces in Indonesia that has a high potency in tourism industry. According to The Ministry of Tourism and Creative Economy, West Java is the second place that most visited by the tourists. In order to make West Java becomes a center of Culture and International Tourism Destination, West Java optimize their own resource to develop their tourism industry. With the development of the tourism industry expected regional awn revenue continue to incrise in West Java province.

Table 1 shows us that Regional Own Revenue of West Java from 2004-2014 has a reduction and enhancement. It was $14 \%$ highest amount of enhancement in 2009-2014, but there were no enhancements in the following years, even it decreased become $1 \%$ in 2014.

TABLE I. REgIONAL OWN REVENUE GROWTH WEST JAVA PROVINCE YEAR 2009-2014 (IN RUPIAHS)

\begin{tabular}{|l|l|l|l|}
\hline No & \multicolumn{1}{|c|}{ Year } & Total Revenue & \multicolumn{1}{c|}{ Percentage } \\
\hline $\mathbf{1}$ & 2009 & $321,836,249,491$ & \\
\hline 2 & 2010 & $324,754,605,150$ & $1 \%$ \\
\hline 3 & 2011 & $365,689,539,567$ & $13 \%$ \\
\hline 4 & 2012 & $417,930,754,626$ & $14 \%$ \\
\hline 5 & 2013 & $421,794,637,554$ & $1 \%$ \\
\hline 6 & 2014 & $417,184,938,798$ & $-1 \%$ \\
\hline
\end{tabular}

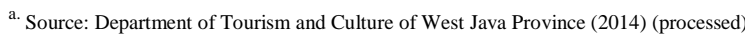

From table 1 and 2 we can see that Regional Own Revenue still couldn't cover the Regional Expenditure, even it was increasing for few years. There are some problems why it was not covered. The tax resource and regional distribution which are the main component of regional Own Revenue, are not optimized enough so it cannot make an optimal contribution to the overall regional expenditure. Therefore, the region still relies to the government. 
TABLE II. EGIONAL EXPENDITURE REALIZATION YEAR 2009-2014 (IN RUPIAHS)

\begin{tabular}{|l|l|l|}
\hline \multicolumn{1}{|c|}{ No. } & \multicolumn{1}{|c|}{ Year } & \multicolumn{1}{c|}{ Total Expenditure } \\
\hline 1 & 2009 & $29,652,139$ \\
\hline 2 & 2010 & $34,247,796$ \\
\hline 3 & 2011 & $40,207,086$ \\
\hline 4 & 2012 & $46,363,883$ \\
\hline 5 & 2013 & $55,078,037$ \\
\hline 6 & 2014 & $60,148,106$ \\
\hline
\end{tabular}

So that regional autonomy could be done, local governments must master sectors to boost tourism Regional Own Revenue. It is consistent with previous research Rantetadung,M.[4], which states that only the number of tourist arrivals that affect reception Regional Own Revenue. Suartini, N. N., dan Utama, M. S.[5] research results that the number of tourist visits, entertainment tax, hotel tax, and restaurants significantly influence Regional Own Revenue district Gianyar. Tendean, J. C.,Palar, S.Wim., dan Tolosang, K. D. [6] This study matches the number of tourists direct positive effect on Regional Own Revenue. Udayantini, K. D., Bagja, I. W., dan Suwendra, I. W. [7] indicates that there is the influence of the number of tourists, hotel occupancy rates on the income of the tourism sector, there is a positive influence on the number of tourists to the tourism revenue, there is a positive effect on the occupancy rate of the tourism revenue, and there is a positive influence on the number of tourists to the hotel occupancy rate at discrit Buleleng. Pertiwi, N. L. G. A. [8] that the number of tourist arrivals, revenue object tourism, hotel and restaurant taxes significantly influenceRegional Own Revenua at discrit Gianyar in Fiscal Year 1993 -2012. Ardahaey, F. T [9] say that tourism is an activity that involves a large array of retail and service businesses. The sectors most affected by tourism are hotels and other lodging facilities, eating and drinking establishments, and amusement and recreation facilities such as theme parks and ski resorts. Zaei, M. E., dan Zaei, M. E [10] say tourism activities increase the tax-revenue of the centre and the state governments (Gee et al., 1989). Many types of taxes are included in tourist-related goods and services. All tourist earnings increase many economic activities in the countries and these economic activities are a big source of taxable earnings for the governments.

Based on previous studies, there are several differences in both variables studied and the results of his research. Researchers are interested to examine the effect of tourist visits to Regional Own Revenue. Similarity variables used are tourist visits. The difference of this study was the object under study, as well as the methods used in the research. From the background and previous studies found no one has studied the effect of tourist arrivals in the province of West Java. Researchers interested in conducting research focused on How to influence the number of tourist visits to the region income in West Java Province 2009-2014.

\section{A Theoretical Framework}

\section{A. Regional Own Reveneue Concept}

According to Law No. 32 of 2004 Article 1 (18) [11], regional Own Revenue is an income that is collected based on the region regulations which is convenient with regulation of legislation. Regional Own Revenue is aimed to give the authority the regions to fund their own implementation of autonomy according to their potency as a realization of decentralization. Mardiasmo [12] described, "Regional Own Revenue is a regional own revenue from regional tax sector, regional retribution, an outcome from regional own enterprise's maintaining, a divided outcome from wealth maintaining, and another legal income. The resource of regional Won Revenue in Law No. 33 of 2004 Article 6,[13] tells that Regional Own Revenue comes from Regional own revenue (regional tax revenue, regional retribution, an outcome from regional own enterprise's maintaining, a divided outcome from regional wealth maintaining, and another legal income), Fiscal Balance Transfers, Regional Loan, and another legal income (including sales from regional wealth which is not divided, giro, interest revenue, an advantage of curs deviation and commission, reduction, or another sales of goods and services by the regions).

\section{B. Tourism Concept}

Tourism is usually associated as a chain of someone journey (tourist) to a destination in order to have a vacation, enjoying the nature and culture, business, visiting families, and etc. Referring to Law No 10 of 2009 [14] explains that tourism is an activity of tour which is supported by many kind of facility and services and provided by the citizens, entrepreneur, government and regions. Meanwhile, Fennel in Pitana and Diarta [15] defines that tourism is "Tourism is defined as the interrelated system that includes tourists and the associated services that are provided and utilized (facilities, attractions, transportation, and accommodation) to aid in their movement."

According to Law No 10 of 2009 [16] about tourism, Tour is an activity or half of that activity for a while which is done willingly to enjoy the tourism object and tourism attraction. Tourism is everything related to its execution. Tourism Business is everything related to services of tourism and another business of that services, Tourism Object and Tourism Attraction is everything related to tourist destination, Tourism Zone is a certain zone that is wide and built or provided to fulfil tourism needs. Tourist is someone who travels from their own place to another place in order to enjoy their journey and their visit. The goal is not for staying, and it's not for money earning.

\section{The Relation between Regional Own Revenue with Regional Autonomy.}

Regional Autonomy will give a good impact in economic sector, where this regional economy is measured by how much Regional Own Revenue collected. If the regional own revenue of the regions are increasing, we can tell that regions are more independent. Yoeti [17]said that, "developing tourism as an industry, will help government increases devise gain faster in 
order to expand the economy. Inkson and Minneart also said that "Tourism can be a source of income for the government via taxes ". Indraningrum, T [18] in her research "The Impacts of General Allocation Fund and Regional Own Revenue in Direct Expenditure" said when the regional own revenue cannot covered its regional expenditure, the government will give the General Allocation Fund to help them maintaining their economic policy effectively and efficiently. The aim of this transfer is to decrease fiscal gap between government and regions and to ensure the standard of public services minimum in all over country. Maimunah [19].

\section{RESEARCH METHODS}

This research used descriptive and verivicative method.

The data was collected by using documentation study technique. The research used the annual data that is published by Dinas Pariwisata dan Kebudayaan Provinsi Jawa. Type of research is descriptive and verification. Sukmadinata [20] stated that the descriptive research method is a method which seeks to describe, interpret things, such as the condition or relationship, a growing opinion, the ongoing processes, results or effects that occur or trends that are taking place. Verification research, according Arikunto [21] "Verification reasearch basically wanted to test the truth of a hypothesis which is implemented through field data collection".

Data collection techniques in this study using the study documentation, in the form of an official document issued by Dinas Pariwisata dan Kebudayaan Provinsi Jawa Barat.The data source consists of the number of tourists' visit and regional own revenue from 26 cities and regencies in West Java during 6 years in 2009-2014.

The data was analyzed by using simple linear regression analysis, which is preceded by a test for linearity as a prerequisite regression test then testing the significance of regression ( $F$ test) and regression coefficient significance test ( $\mathrm{t}$ Test). The hypothesis in this research is:

$\mathrm{H}_{\mathrm{o}}: \beta=$ The Number of Tourists' Visit doesn't impact the regional own revenue.

$\mathrm{H}_{1}: \beta>$ The Number of Tourists' Visit impact regional own revenue

\section{RESULTS \& DISCUSSIONS}

The success of tourism sector will increase their role in regional income gain because it is one of many instruments which ensure devise gain out of oil and gas industry. Oil and gas industry are resources that cannot be regenerated. Whereas, tourism sector still can be improved in many ways as long as technology is increasing. The existence of tourism destination in a region will be an enticement for domestic or foreign tourists. Those tourism zone will raise many kind of other industries that support tourism in that area, such as hospitality, regional souvenirs, culinary business or restaurant, travel agent, transportation business, and etc. All of them are needed by the tourists as long as they stay in that area.

Tourist will go to the restaurant to fulfill their food needs. The will stay at hotels to fulfill their dwelling needs.
They will also buy some souvenirs to satisfy themselves, they will rent transportation services while they're travelling, they will pay for the tickets in every destination they visit, and they will pay for park their vehicles of course. The money that is spent buy them in every tourism area, will be a direct income for government through tax revenue that is gained from every business component in that place. The more it's popular, the higher number of tourists will visit the place.

The main aim of this research is to analyse and prove the impact of tourists' visit number on the regional own revenue in West Java Province. The data was collected from legal document, such as Annual Report from Tourism and Culture of West Java which is published by Dinas Pariwisata dan Kebudayaan Jawa Barat, and Recapitulation of Income and Expenditure from Cities and Regencies, published by Badan Pusat Statistik Provinsi Jawa Barat. After that, the data was analyzed and hypnotized.

The research was studied empirically to know how the number of tourists' visit impacts The Regional Own Revenue. The analysis test used simple linier regression analysis in order to measure the impact of tourists' number visit on Regional Own Revenue. This is the following result:

$$
\begin{aligned}
& \hat{Y}=a+b X \\
& \hat{Y}=7.392 .394 .485,303+6.526,834 X
\end{aligned}
$$

a. 7.392.394.484, 303Constanta, shows if the number of tourist's visit doesn't have any change, the regional own revenue will have 7.392.394.484, 303 constanta.

b. The direction of relation shows a positive one. It means, if the number of tourists' visit is increasing, the regional own revenue will increase too. And it is also the otherwise.

c. 6526,834 regression of coefficient means if the ratio of tourist's visit increases 1 person, the regional own revenue will increase $6.526,834$ times.

After that, this research was studied by significance test $(\mathrm{F}$ Test) with standard of significance is $5 \%$. The result shows that $F_{\text {hitung }}$ is 12,424 and $F_{\text {tabel }}$ is $3,90\left(\mathrm{~F}_{\text {hitung }}>\mathrm{F}_{\text {tabel }}\right)$ so we can see that $\mathrm{H}_{\mathrm{o}}$ is declined and $\mathrm{H}_{1}$ is accepted and the conclusion is that regression is signified

Aside from $\mathrm{F}$ test, the research was studied with regression of coefficient significance test ( $\mathrm{T}$ test), with one side test of $\mathrm{t}_{\text {tabel }}$ and 0,05 or $5 \%$ standard of significance. Then it is known that df156 - $2=154(\mathrm{n}-\mathrm{k})$ and the value is 1,65481 . The $t_{\text {tabel }}$ shows that $t_{\text {hitung }}>t_{\text {tabel }}$ which means 3,525 >1, 65481, so that $\mathrm{H}_{\mathrm{o}}$ is declined. It means the number of tourists' visit has a positive impact on Regional Own Revenue. The results are consistent with Inkson and Minneart [22]"tourism can be a source of income for the government via taxes". This research also proved that tourists who come will spend their money to fulfill their needs Holloway and Humphreys [23]. Various amenities which is needed by those tourists such as product of goods and services, are also mentioned by in Sihite [24],"the tourism industry creates some products such as goods and services which are needed by the tourists during their journey ". 
Moreover, Tendean, J. C.,Palar, S.Wim., dan Tolosang, K. D [25] said in their research which the title is The Impact of Tourists' Visit Number on Regional Own Revenue in Manado City as Intervening Variable, found that the number of tourists' visit has a positive impact, so if he number of tourists' visit is increasing, the regional own revenue will increase too. The number of tourists' visit effects hotel tax. It also happens with the research by Karisma, W. [26] in her study Analysis of Tourism Sector Role on Regional Own Revenue in Wonosobo Regency, which has a conclusion that tourism industry that consist of retribution of tourism object, the number of domestic and foreign tourists, have a positive effect on regional own revenue. Meanwhile Nadia, F., dan Retno, H. [27] in their research The Impact of Tourists' Visit Number, Tourism Object Number, and Gross Domestic Product on Tourism Sector Income in Kudus Regency, said that the number of tourists' visit is a dominant factor to increase Tourism Sector Income. Tourist existence becomes more important in regional income enhancement, because the money that is spent by the tourist will be a direct income for the government through tax gain. The enhancement of every income source should be done by all regions, in order to fulfil their own expenditure needs without having transfer from the government. Tourism industry has an important role to increase regional income in that region. Therefore, tourists' visit should be increased in order to maximize all income source. All people will get those advantages by optimizing tourism sector. The tourists that come along to tourism area gives a long term multiplier effect for government or citizen.

There is also the research results can be a source of information to interested parties and for the development of the science of International Public Sector Accounting Accounting especially with studies the importance of efforts to increase regional revenue management trerkait levy, entertainment tax, restaurant tax and hotel tax. Besides the practical level the results of this study can be considered the determination of policies concerning taxes imposed on attractions, restaurants, hotels and entertainment venues that tax collection can be done with the maximum. Become a reference and a reference to the West Java Province Government and the Department of Tourism and Culture of West Java Province related to the development of the tourism industry to improve the original own revenue.

\section{CONCLUSION AND SUGGESTIONS}

\section{A. Conclusion}

Based on the result of descriptive and verivicative test, we can conclude since 2009 The Regional Own Revenue was increasing even since 2012 didn't increase too much, even it was decreasing in 2014. The result shows that the number of tourists' visit has a positive effect on regional own revenue. The enhancement of tourists' visit will impact the enhancement of Regional Own Revenue, and so is the otherwise. The government should increase the number of tourists'visit both foreign and domestic. Development of tourism destination concept through Community Based Tourism (CBT) can be a good alternative way with society empowerment in local area which is far from urban areas.
Meanwhile, the urban areas can improve MICE (Meeting, Intensive, Conference and Exhibition) concept. MICE is a concept based on tourism business. It is suggested for other researcher to expand the variables of study, so this research can be more specific and various in another point of view, like from economic condition, inflation, education level, and etc.

\section{REFERENCES}

[1] Undang-undang Nomor 32 tentang Pemerintah Daerah Tahun 2004.

[2] Deddi dan Ayuningtyas. Akuntansi Sektor Publik. Jakarta: Salemba Empat 2011

[3] Suwantoro, G. Dasar-dasarPariwisata.Yogyakarta :Andi.2004

[4] Rantetadung,MAnalisisPengaruhDukunganPemerintahdanKunjunganWi satawanterhadapPendapatanAsli Daerah di KabupatenNabire. Nabire: JurnalAgroforesti .2012.Vol.7, No.1, hal.26-31

[5] Suartini, N. N., dan Utama, M. SPengaruh Jumlah Kunjungan Wisatawan, Pajak Hiburan, Pajak Hotel dan Restoran terhadap Pendapatan Asli Daerah di Kabupaten Gianyar. E-Journal Ekonomi dan BisnisUniversitasUdayana, . 2013. Vol. 2, No. 3, hal 175-189.

[6] Tendean, J. C.,Palar, S.Wim., dan Tolosang, K. D. PengaruhJumlahWisatawanTerhadapPendapatanAsli Daerah (PAD) Kota Manado MelaluiPajak Hotel Sebagai Intervening Variabel. Manado: Jurnal Berkala Ilmiah Efisiensi, 2014. Vol. 14, No. 3, hal. 115.

[7] Udayantini, K. D., Bagja, I. W., dan Suwendra, I. W. PengaruhJumlah Wisatawan Dan Tingkat Hunian Hotel Terhadap Pendapatan Sektor Pariwisata Di Kabupaten Buleleng Periode 2010-2013.Singaraja:eJournal Bisma Universitas Pendidikan Ganesha Jurusan Manajemen, 2015. Vol. 3, hal. 2-10

[8] Pertiwi, N. L. G. A. Pengaruh Kunjungan Wisatawan, Retribusi Obyek Wisata Dan Pajak hotel dan restoran Terhadap Pendapatan Asli Daerah Kabupaten Gianyar: E-Journal Ekonomi Pembangunan UniversitasUdayana, 2013. Vol.3, No. 3, hal. 115-123.

[9] Ardahaey, F. T. Economic Impacts of Tourism Industry. Tehran. International Journal of Business and Management .2011. Vol. 6, No. 8, hal.206-215.

[10] Zaei, M. E., dan Zaei, M. E. The Impacts Of Tourism Industry On Host Community. Delhi. European Journal of Tourism Hospitality and Research. 2013. Vol.1, No.2, hal.12-21.

[11] Undang-undang Nomor 32 tentang Pemerintah Daerah Tahun 2004.

[12] Mardiasmo. Otonomi dan Manajemen Keuangan Daerah.Yogyakarta: Andi. 2004.

[13] Undang-undang Nomor 32 tentang Pemerintah Daerah. Tahun 2004

[14] Undang-undang Nomor 10 tentang Kepariwisataan Tahun 2009

[15] Pitana, I. G., dan Diarta, I.S. Sosiologi Pariwisata. Yogyakarta: Andi.2009.

[16] Undang-undang Nomor 10 tentang Kepariwisataan Tahun 2009

[17] Yoeti, O. A. Ekonomi Pariwisata. Jakarta: Kompas Media. 2008.

[18] Indraningrum, T. Pegaruh Dana Alokasi Umum (DAU) dan Pendapatan Ali Daerah terhadap Belanja Langsung (Studi Pada Pemerintah Daerah Kabupaten/Kota di Provinsi Jawa Tengah. 2011.

[19] Maimunah, M. Flypaper Effect pada Dana Alokasi Umum (DAU) dan Pendapatan Asli Daerah (PAD) terhadap Belanja Daerah pada Kota/Kabupaten di Pulau Sumatera. Tesis. Yogyakarta: Program Pascasarjana Universitas Gajah Mada. 2006.

[20] Sukmadinata. Metode Penelitian Pendidikan. Bandung: Remaja Rosdakarya . 2006.

[21] Arikunto,S. Prosedur Penelitian Suatu Pendekatan Praktis. Yogyakarta: Bina Darmadji Aksara .2009.

[22] Inkson, C., dan Minnaert, L. Tourism Management. London: SAGE Publications, Ltd. 2012.

[23] Holloway, J. C., dan Humphreys, C. The Business of Tourism. Edinburgh: Pearson Education, Ltd. 2012.

[24] Sihite, R. Tourism Industry (Kepariwisataan). Surabaya: SIC. 2000. 
[25] Tendean, J. C.,Palar, S.Wim., dan Tolosang, K. D. Pengaruh Jumlah Wisatawan Terhadap Pendapatan Asli Daerah (PAD) Kota Manado Melalui Pajak Hotel Sebagai Intervening Variabel. Manado: Jurnal Berkala Ilmiah Efisiensi, 2014. Vol. 14, No. 3, hal. 1-15.

[26] Karisma,W. Analisis Peran Industri Pariwisata terhadap Pendapatan Asli Daerah Kabupaten Wonosobo. 2013.

[27] Nadia, F., dan Retno, H. Pengaruh Jumlah Kunjungan Wisatawan, Jumlah Obyek Wisata Dan Pendapatan Perkapita Terhadap Penerimaan Sektor Pariwisata Di Kabupaten Kudus. Kudus: Diponegoro Journal of Economics . 2013. Vol. 2, No. 2, hal. 1-9 